\title{
PROGNOSTIC VALUE OF CARCINOEMBRYONIC ANTIGEN DISTRIBUTION IN TUMOR TISSUE OF COLORECTAL CARCINOMA
}

\author{
Débora Maria NAZATO'1†, Leandro Luongo de MATOS², Daniel Reis WAISBERG ${ }^{3}$, \\ José Roberto Martins de SOUZA ${ }^{3}$, Lourdes Conceição MARTINS ${ }^{1}$ and Jaques WAISBERG ${ }^{3}$
}

\begin{abstract}
Context - Carcinoembryonic antigen (CEA) can be detected in colorectal tumor tissue but its role in the survival of patients remains controversial. Objective - To characterize the expression of tissue CEA using immunohistochemical staining in colorectal tumors and to analyze the relationship between this finding and preoperative plasmatic level of CEA, morphologic features and survival of patients operated with curative intent for colorectal carcinoma. Method - Forty-seven patients were included in the study: 18 (38.3\%) males and 29 (61.7\%) females, with a mean age of $67.8 \pm 9.7$ years ( 37 to 84 years). Immediately before laparotomy, pre-operative serum levels of CEA were obtained where normal levels were considered $\leq 2.5 \mathrm{ng} / \mathrm{mL}$ for non-smokers, and $\leq 5.0 \mathrm{ng} / \mathrm{mL}$ for smokers. CEA immunohistochemical studies were carried out using anti-human CEA monoclonal mouse antibody. The expression of immunostaining for each neoplasia was classified according to the pattern of CEA tissular distribution into apical or cytoplasmic. The variables considered for the statistical analysis were plasmatic preoperative CEA level, location of the lesion within the large intestine, lesion diameter, lymph node involvement, Duke's classification, vein invasion, grade of cellular differentiation, survival and pattern of CEA tissular distribution. The statistical models utilized were Spearman's correlation and the Mann-Whitney, Kruskal-Wallis and Student $t$ tests. Patients' survival was analyzed using the KaplanMeier method. Results - The mean preoperative CEA value was $15.4 \pm 5.5 \mathrm{ng} / \mathrm{mL}(0.2$ to $92.1 \mathrm{ng} / \mathrm{mL})$. The neoplasm was located in the colon in $29(61.7 \%)$ and in the rectum in $18(38.3 \%)$ patients. Eight (17.0\%) patients were classified as Duke's stage A, $22(46.8 \%)$ as stage B and $17(36.2 \%)$ as stage C. On immunohistochemical studies, the pattern of CEA tissular distribution was apical in $33(70.2 \%)$ patients and cytoplasmic in $14(29.8 \%)$ patients. Patients with apical patterns presented a mean sera CEA level of $15.5 \pm 6.5 \mathrm{ng} / \mathrm{mL}$ while those with cytoplasmic pattern attained a mean sera CEA level of $15.1 \pm 7.3 \mathrm{ng} / \mathrm{mL}$, with no significant difference between these values $(P=0.35)$. Apical distribution of CEA occurred in 6 (12.8\%) Duke A, 18 (38.2\%) Duke B and 9 (12.2\%) Duke C patients, while cytoplasmic CEA tissular distribution was observed in 2 (4.2\%) Duke A, 3 (6.4\%) Duke B and 9 (19.1\%) Duke C patients. Patients with Duke B neoplasms presented significantly more apical CEA tissular distribution patterns $(P=0.049)$ than subjects with cytoplasmic CEA tissular patterns. The apical CEA tissular distribution pattern in neoplasms was significantly more frequent in neoplasms with no lymph node compromise compared to the cytoplasmic pattern $(P=0.50)$. However, no significant differences were seen between apical and cytoplasmic CEA tissular distribution patterns in terms of colon or rectal site $(P=0.21)$, lesion diameter across greatest axis $(P=0.19)$, vein invasion $(P=0.13)$ or degree of cellular differentiation $(P=0.19)$. Of the 47 patients operated, $33(70.2 \%)$ survived for more than 5 years where mean survival was $31.1 \pm 5.6$ months. Survival between patients with apical and cytoplasmic CEA tissular distribution showed no significant difference $(P=0.38)$. Conclusions - Although the apical distribution pattern of CEA was significantly more frequent in more advanced stages of Duke's classification, the CEA tissular distribution presented no relationship with serum CEA levels, morphological features of the neoplasm or survival of patients undergoing curative colorectal carcinoma resection.
\end{abstract}

HEADINGS - Colorectal neoplasms. Carcinoma. Carcinoembryonic antigen. Immunohistochemistry.

+ Supported by PIBIC/CNPq, Brazil

Departments of ${ }^{1}$ Medicine, ${ }^{2}$ Surgery, "Faculdade de Medicina do ABC, Santo André, SP., ${ }^{3}$ Department of Surgery, "Hospital do Servidor Público Estadual de São Paulo", São Paulo, SP, Brazil.

Correspondence: Dr. Jaques Waisberg - Rua das Figueiras, 550 - apt. 134 - Bairro Jardim - 09080-300 - Santo André, SP, Brazil. E-mail: jaqueswaisberg@uol.com.br 


\section{INTRODUCTION}

Colorectal cancer (CRC), with its high incidence and significant morbidity and mortality, remains one of the leading causes of cancer-related death worldwide ${ }^{(14)}$. Several small-scale retrospective studies have demonstrated that CRC patients with high preoperative levels of CEA have a worse prognosis than those with low levels ${ }^{(8,30)}$. Preoperative CEA thus has the potential to supply prognostic data independent of the traditional staging systems in patients with $\mathrm{CRC}^{(6,7,8,19,21,25,28)}$.

CEA can also be detected and quantitatively measured in

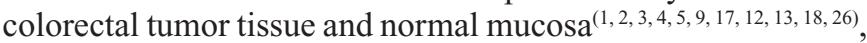
but its role in the management of colorectal cancer remains controversial ${ }^{(4,11,20)}$. Some authors have reported that elevated CEA concentrations within the tumor are correlated with advanced stage $^{(3,4,7,18,22,25,26)}$, whereas other studies have not reached this conclusion $^{(5,16,20)}$. In addition, COSIMELLI et al. ${ }^{(5)}$ reported that elevated CEA concentrations within colorectal cancer was a predictor for local and distant tumor recurrence after surgery, independent of other recognized prognostic variables (stage and histological grade). On the contrary, others ${ }^{(9,20)}$ have found no association between tumor CEA concentrations and tumor relapse after surgery. Besides, it is necessary to know whether effectively, a relationship exists between the values of CEA measured in sera and colonic mucosa, as well as with the distinct morphological characteristics, to establish the true value of monitoring CEA in follow-up.

The purpose of this study was to characterize the expression of tissue CEA using immunohistochemical staining in colorectal tumors and to investigate whether it contributes additional information with respect to serum CEA levels, morphologic features, and survival of patients operated for colorectal carcinoma with curative intent.

\section{METHOD}

This study analyzed 47 colorectal carcinoma patients who underwent curative surgical treatment between July 1999 and June 2002. The study was approved by the Ethics Committee of both institutions and all patients signed an informed consent form.

The term curative denoted absence of macroscopic neoplasm residual disease following the operation, according to preoperative stage and intra-operative assessment by the surgeon, and the presence of free surgical margins around the resection specimen.

Of the 47-patient sample, $18(38.3 \%)$ were male and 29 $(61.7 \%)$ female. Forty-one (87.2\%) were white and six (12.8\%) were black. Mean age was $67.8 \pm 9.7$ years ( 37 to 84 years).

The following were adopted as inclusion criteria: presence of carcinoma of the large intestine confirmed by histopathological study of the extirpated lesion, absence of distant metastases at preoperative examinations and in the abdominal cavity inventory made during the operation, and extirpation of the neoplasm lesion with curative intent. The exclusion criteria were the presence of distant metastases and incomplete extirpation of the neoplasm lesion.
All the patients had histological diagnoses of colorectal carcinoma confirmed via review of thin sections stained using the hematoxylin and eosin (H-E) method and analysis by a pathologist. The preoperative evaluation consisted of the clinical and proctologic examinations, colonoscopy, determination of the serum level of CEA, abdominal sonography, abdominal computed tomography, and chest radiography. All the colorectal lesions were extirpated with curative intent.

Immediately before laparotomy, peripheral venous blood was extracted by antecubital venous puncture. The peripheral serum samples were stored in a freezer at $-70^{\circ} \mathrm{C}$ until the CEA analyses were performed. For assaying of the CEA, a solidphase fluoroimmunometric assay was utilized (Delfia CEA Kit, Pharmacia, Turkü, Finland). Normal pre-operative levels for CEA in serum of patients with colorectal carcinoma were considered $\leq 2.5 \mathrm{ng} / \mathrm{mL}$ for non smokers and $\leq 5.0 \mathrm{ng} / \mathrm{mL}$ for smokers. Surgical specimens were fixed in $10 \%$ formalin solution and embedded in paraffin where three $4 \mu \mathrm{m}$ sections were taken from the sample for histopathological diagnosis. The conventional sections were stained with $\mathrm{H}-\mathrm{E}$.

Immunohistochemical staining was performed according to the standard avidin-biotin immunoperoxidase complex technique (LSAB ${ }^{\circledR}$, DakoCytomation, Glostrup, Denmark). Mouse monoclonal anti-human carcinoembryonic antigen antibody (clone II-7, DakoCytomation, Glostrup, Denmark) was used as the primary antibody.

The brownish-color was considered to be evidence of a positive expression of CEA in the tumor cells. Immunostaining expression (Figure 1) was classified according to the pattern of cytoplasmatic distribution: (1) cytoplasmic type, in which immunostaining was homogeneously in the cytoplasm of neoplasic cells; (2) apical type in which, independent of cell staining, there was predominant immunostaining on the cytoplasmatic edge closest to the lumen of the neoplasic tissue cells ${ }^{(11,27)}$. There was no membrane immunostaining.

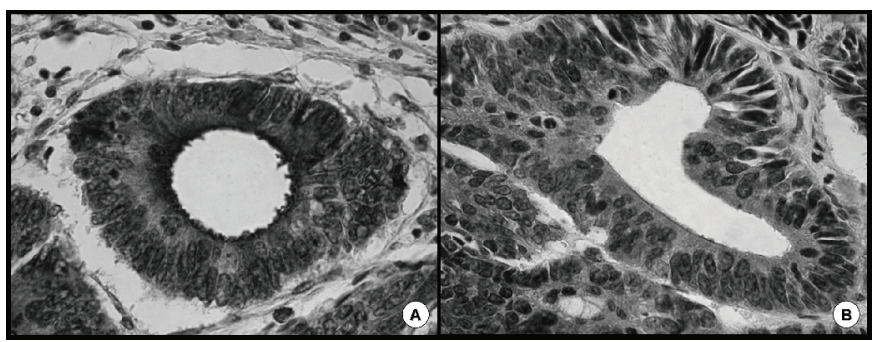

FIGURE 1. Patterns of CEA tissue staining in colorectal adenocarcinoma demonstrating the two types of tissular distribution types ( $A$ and $B$ ) on immunohistochemical study using anti-CEA monoclonal antibody. (A) Apical pattern, in which highest levels of immunostaining were situated at the edge closest to lumen of neoplasic cells; (B) cytoplasmic pattern, in which immunostaining predominates in cytoplasm of neoplasic cells ( $\mathrm{x} 400$ )

The variables considered for the purposes of statistical analysis were age, sex, location of the lesion within the large intestine, peripheral preoperative CEA level, lesion diameter, Duke's classification, lymph node involvement, presence or absence of vein invasion by the neoplasm, grade of cellular 
differentiation, survival and pattern of tissular distribution of CEA in colorectal carcinoma.

Parametric and non-parametric statistical tests were used according to the nature of the samples. The quantitative variables were represented by absolute frequency $(\mathrm{N})$ and relative frequency (percentage). The statistical models utilized were arithmetic mean, median, standard deviation, Spearman's correlation, the MannWhitney test, Kruskal-Wallis test and Student $t$ test. Patients' survival was analyzed using the Kaplan-Meier method. For every test, the level for rejection of the null hypothesis was set at 0.05 (95\% significance level), in accordance with the current standards for biological studies.

\section{RESULTS}

The mean preoperative CEA value was $15.4 \pm 5.5 \mathrm{ng} / \mathrm{mL}$ ( 0.2 to $92.1 \mathrm{ng} / \mathrm{mL}$ ). The mean sera CEA level was $3.4 \mathrm{ng} / \mathrm{mL}$ in Duke A patients, $16.1 \mathrm{ng} / \mathrm{mL}$ in Duke B, and attained $18.9 \mathrm{ng} / \mathrm{mL}$ in Duke C subjects. Sera CEA values greater than $10 \mathrm{ng} / \mathrm{mL}$ occurred in $12(33.4 \%)$ patients.

The neoplasm was located in the colon in $29(61.7 \%)$ and in the rectum in 18 patients $(38.3 \%)$. Eight (17.0\%) patients were classified as Duke's stage A, $22(46.8 \%)$ as stage B and $17(36.2 \%)$ as stage $\mathrm{C}$. The mean of the largest dimension of the tumor was $5.4 \pm 2.2 \mathrm{~cm}$, ranging from 0.8 to $12.0 \mathrm{~cm}$.

Nineteen $(40.4 \%)$ patients presented no lymph node compromise, while $28(59.6 \%)$ had carcinoma-invaded lymph nodes. The neoplasm had invaded up to adjacent adipose tissue in $37(78.7 \%)$ patients, and the lesion had spared the serosa of the large intestine in $10(21.3 \%)$ patients. Angiolymphatic invasion was observed in $29(61.7 \%)$ patients. In 35 (74.5\%) patients, the histological grade of the carcinoma was moderately differentiated, while in 11 (23.4\%) was well differentiated, and was slightly differentiated in one (2.1\%) subject.

On immunohistochemical study, the pattern of tissular distribution of CEA was apical in $33(70.2 \%)$ patients and cytoplasmic in $14(29.8 \%)$ patients. Patients with an apical pattern of tissular CEA distribution presented a mean sera level of $15.5 \pm 6.5 \mathrm{ng} / \mathrm{mL}$ while those with cytoplasmic patterns of tissular CEA attained a mean sera CEA level of $15.1 \pm 7.3 \mathrm{ng} / \mathrm{mL}$. These results presented no significant difference $(P=0.35)$. Apical tissular distribution of CEA was observed in $6(12.8 \%)$ Duke A, 18 (38.2\%) Duke B, and 9 (12.2\%) Duke C patients, while cytoplasmic CEA tissular distribution was observed in 2 (4.2\%) Duke A, 3 (6.4\%) Duke B and 9 (19.1\%) Duke C patients. Patients with Duke B neoplasms presented significantly more apical CEA tissular distribution patterns $(P=0.049)$ than subjects with cytoplasmic CEA tissular patterns.

The apical pattern of CEA distribution in neoplasms was significantly more frequent $(P=0.50)$ in neoplasms with no lymph node compromise compared to the cytoplasmic pattern. Moreover, no significant differences were seen between apical and cytoplasmic CEA tissular distribution patterns in terms of colon or rectal site $(P=0.21)$, lesion diameter across greatest axis $(P=0.17)$, vein invasion $(P=0.13)$ or grade of cellular differentiation $(P=0.19)$.
A total of $14(29.8 \%)$ patients presented carcinoma recurrence during follow up. The liver was affected in $10(21.3 \%)$ patients while the remaining $4(8.5 \%)$ subjects manifested peritoneal carcinomatosis. Of the 47 patients who underwent surgery, $33(70.2 \%)$ survived for more than 5 years (Figure 2). Mean survival was $31.1 \pm 5.6$ months. Survival of patients with apical or cytoplasmic tissular CEA distribution did not differ significantly $(P=0.38)$.

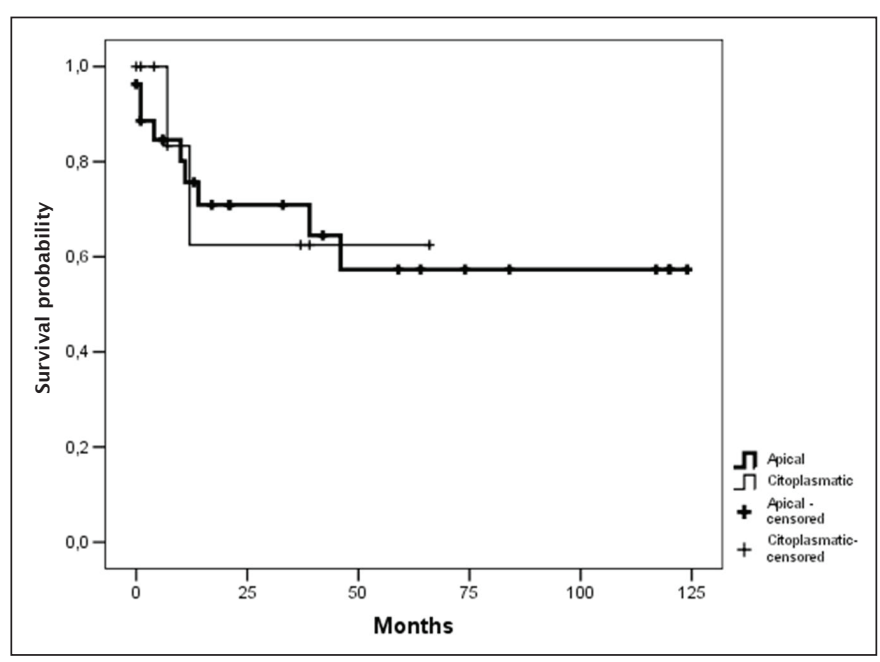

FIGURE 2. Kaplan-Meier survival curve of patients with apical or cytoplasmic CEA tissular distribution in curative colorectal carcinoma resection

\section{DISCUSSION}

Patients with high levels of CEA in preoperative serum and producers in tissue are those alerted in the pursuing that its values in the serum will provide us a bigger yield in the detection of metastases ${ }^{(18,22)}$. Nevertheless, in patients not producing CEA in tissue or serum, the determination in the pursuing would not be so useful ${ }^{(18)}$. It is a combination of the values of CEA detected in blood and tissue that could improve prognostic sensitivity and allow a better interpretation of the obtained values ${ }^{(18)}$.

In the cytoplasmic distribution, tissular CEA can spread more easily to stroma and enter circulation, justifying that this tumoral type, even with equal amounts of tissular CEA correlate with high levels of serum $\operatorname{CEA}^{(3,9,11,15,29)}$. On the other hand, levels of serum CEA do not correspond with the level of tissular CEA in some individuals ${ }^{(11,18,20)}$. Indeed, the present study indicated the absence of a relationship between pre-operative CEA sera levels and tissular distribution of CEA.

In vitro studies have disclosed that promotion of blocking of colonic mucosa cell polarization in a calcium-poor culture medium leads to intracellular build up of $\mathrm{CEA}^{(23,24)}$. This phenomenon appears to occur due to the incapacity of cells with blocked polarization to excrete the antigen to the intestinal lumen. Progressive CEA accumulation within cellular cytoplasm of cells undergoing differentiation has been observed, which suggests that loss of polarization may by linked to lower levels of differentiation ${ }^{(23,24)}$. This finding suggests that although there 
is a greater quantity of CEA produced or accumulated within cell cytoplasm, the antigen is more dispersed in the cytoplasmatic pattern than the apical pattern.

The classification of the tumor must be considered because there are factors in the invasion of the wall that facilitate CEA penetration into the bloodstream ${ }^{(3,4,11)}$. The existence of tumoral necrosis, perineural and perivascular infiltration, as well as infiltration degree, positively influence levels of serum $\mathrm{CEA}^{(11,18,20)}$. Correlation between tissular CEA and serum CEA does not appear strong in the different studies reviewed $^{(3,11,16,18)}$. Highly differentiated tumors with high levels of apical distributed tissular CEA may present low levels of sera CEA because secretions may enter intestinal lumen and under these conditions CEA has difficulty in reaching the blood stream $^{(3,11,16,18)}$. However, with tumors having cytoplasmic distribution of CEA, tissular antigen may spread more easily to the stroma and enter systemic circulation, leading to higher sera CEA levels ${ }^{(17)}$. GEBAUER et al. ${ }^{(9)}$ reported that CEA concentrations in colorectal tumor tissue were closely related to the degree of accumulation of CEA positive cells in the neoplastic glands as determined by immunohistochemistry. NG et al. ${ }^{(22)}$ found no relationship between tissular expression of CEA in colorectal carcinoma and pre-operative CEA sera levels. These authors concluded that although the pattern of tissular CEA distribution may prove useful in explaining pathophysiological events related to the carcinogenesis, it offers little additional information over blood CEA levels in treating patients with colorectal carcinoma. Similarly, the current study, along with those previously reported ${ }^{(5,18,22)}$, has revealed no correlation between pre-operative serum CEA and immunohistochemical CEA expression in tumor tissue.

MORENO-CARRETERO et al. ${ }^{(18)}$ reported that CEA concentrations within the colorectal tumor tissue did not predict for patient prognosis after surgery, although these levels did correlate significantly with Dukes stage ${ }^{(10,20)}$. GEBAUSER et al. ${ }^{(9)}$ demonstrated that tumor CEA concentrations did not differ between patients with or without tumor recurrence after colorectal cancer surgery. The present study revealed that patients with Dukes B colorectal carcinoma presented a significant predominance of apical tissular CEA distribution and, accordingly, the pattern of apical CEA distribution in neoplasia was significantly more frequent in neoplasias without lymph node compromise compared to the cytoplasmic pattern, indicating a link between cytoplasmic distribution and more advanced colorectal carcinoma lesions.

The present study observed no relationship between the pattern of tissular CEA distribution and morphological parameters of the neoplasm, except with respect to carcinomas with lymph node compromise which presented significantly greater apical tissular CEA distribution than cytoplasmic when comparing lesions without lymph node compromise. Nevertheless, COSIMELLI et al. ${ }^{(5)}$ reported that a high tumor CEA concentration served as a reliable prognostic index for recurrence, independently of other recognized prognostic factors (DUKES stage and histological grade) on multivariate analysis.
There may be a weak relationship between type of expression and levels of serum CEA, making immunocytochemical assay a practical element to explain these CEA serum levels from a biological standpoint, allowing improved prognostic of serum CEA values ${ }^{(3)}$. Combined CEA values obtained in both blood and tissue may improve prognostic sensitivity and allow better interpretation of values obtained ${ }^{(18)}$. Also, more in-depth knowledge on tissular expression of CEA in neoplasic cells, as well as the dynamic with which the antigen affects the blood stream, constitute important variables for better understanding of colorectal carcinoma evolution. However, in the present study, sera CEA values observed did not differ for apical and cytoplasmic tissular distribution in the neoplasm.

Few studies have reported a relationship between expression or content of CEA in colorectal carcinoma tissue and patient survival. COSIMELLI et al. ${ }^{(5)}$ observed a 2 -year survival rate of $81 \%$ in patients presenting low values of CEA content in tumors and non-neoplasic intestinal mucosa, whilst patients with high content values presented a survival rate of $21.4 \%$. Patients having high tissular CEA content in tumors or nonneoplasic mucosa presented a 2-year survival rate of $65.9 \% \%^{(5)}$. LORENZI et al. ${ }^{(25)}$ affirmed that apical expression for tissular CEA presented a significant relationship with degree of differentiation of the neoplasm while diffuse cellular or cytoplasmic expression of this antigen frequently indicates neoplasms extending beyond the intestinal wall and invading lymphatic veins. Studies by NAKAGOE et al. ${ }^{(20)}$ analyzing the prognostic value of CEA levels in tumoral tissue, normal colonic mucosa and pre-operative CEA sera in patients with resected colorectal carcinoma, concluded that high CEA levels in neoplasic tissue was the sole independent predictor of adverse evolution following colorectal carcinoma resection.

Further studies are needed to evaluate the relationship between the immunohistochemical expression of CEA and prognosis in colorectal carcinoma and to evaluate whether this immunohistochemical staining might be useful as a predictive marker of chemotherapy benefit.

\section{CONCLUSIONS}

Although the apical distribution pattern was significantly more frequent in less advanced stages of Dukes classification, tissular distribution of CEA presented no relationship with plasmatic levels of CEA, morphological features of the neoplasm or survival of patients undergoing curative colorectal carcinoma resection. We conclude that although tissue CEA staining patterns appear useful in explaining pathophysiological features, they offer little additional information over plasma CEA toward the prognosis of patients with colorectal carcinoma operated with curative intent.

\section{ACKNOWLEDGMENT}

The authors thank Juan Francisco Sander Filho for his technical support. 
Nazato DM, Matos LL, Waisberg DR, Souza JRM, Martins LC, Waisberg J. Valor prognóstico da distribuição do antígeno carcinoembriônico (CEA) no tecido neoplásico do carcinoma colorretal. Arq Gastroenterol. 2009;46(1): 26-31.

RESUMO - Contexto - O antígeno carcinoembrionário (CEA) pode ser detectado no tecido do carcinoma colorretal, mas seu papel na sobrevivência dos doentes permanece controverso. Objetivo - Caracterizar a expressão do CEA tecidual com coloração imunoistoquímica na neoplasia colorretal e analisar a relação entre esse achado e os níveis plasmáticos pré-operatórios do CEA, aspectos morfológicos e a sobrevivência dos doentes operados com intenção curativa de carcinoma colorretal. Método - Quarenta e sete doentes foram incluídos neste estudo: 18 (38,3\%) homens e 29 (61,7\%) mulheres, com média de idade de 67,8 \pm 9,7 anos (37 to 84 anos). Imediatamente antes da laparotomia, foram obtidos os níveis plasmáticos pré-operatórios do CEA. Níveis séricos pré-operatórios normais de CEA foram considerados $\leq 2,5 \mathrm{ng} / \mathrm{mL}$ para não-fumantes e $\leq 5,0 \mathrm{ng} / \mathrm{mL}$ para fumantes. O estudo imunoistoquímico do CEA foi realizado utilizando anticorpo monoclonal de rato anti-CEA humano. A expressão da imunocoloração de cada neoplasia foi classificada de acordo com o padrão de distribuição tecidual do CEA em apical ou citoplasmática. As variáveis consideradas para a análise estatística foram os níveis plasmáticos préoperatórios do CEA, localização da lesão no intestino grosso, diâmetro da lesão, comprometimento dos linfonodos, classificação de Dukes, invasão venosa, grau de diferenciação celular, sobrevivência e padrão da distribuição tecidual do CEA. Os modelos estatísticos utilizados foram correlação de Spearman, teste de Mann-Whitney, teste de Kruskal-Wallis e teste $t$ de Student. A sobrevivência dos doentes foi analisada utilizando-se o método de Kaplan-Meier. Resultados - O valor médio de CEA pré-operatório foi de 15,4 $\pm 5,5 \mathrm{ng} / \mathrm{mL}$ (0,2 a 92,1 ng/mL). A neoplasia estava localizada no colo em 29 (61,7\%) e no reto em 18 (38,3\%) doentes. Oito (17,0\%) doentes foram classificados como estádio A de Dukes, 22 (46,8\%) como estádio B e 17 (36,2\%) como estádio C. No estudo imunoistoquímico, o padrão de distribuição tecidual do CEA foi apical em 33 (70,2\%) doentes e citoplasmático em 14 (29,8\%) enfermos. Doentes com padrão apical apresentaram média do nível sérico do CEA de $15,5 \pm 6,5 \mathrm{ng} / \mathrm{mL}$ e os com padrão citoplasmático obtiveram média do nível sérico de CEA de $15,1 \pm 7,3 \mathrm{ng} / \mathrm{mL}$, sem diferença significante entre esses valores $(P=0,35)$. A distribuição apical do CEA ocorreu em $6(12,8 \%)$ doentes Dukes A, 18 (38,2\%) Dukes B e 9 (12,2\%) Dukes C. Por sua vez, a distribuição tecidual citoplasmática do CEA foi observada em dois (4,2\%) enfermos Dukes A, três (6,4\%) Dukes B e nove (19,1\%) Dukes C. Os doentes com neoplasia Dukes B apresentaram padrão de distribuição tecidual de CEA apical significantemente maior $(P=0,049)$ do que os enfermos com padrão tecidual citoplasmático de CEA. O padrão de distribuição apical do CEA na neoplasia foi significantemente mais freqüente nas neoplasias sem acometimento linfonodal quando comparado com o padrão citoplasmático $(P=0,50)$. A localização cólica ou retal $(P=0,21)$, tamanho da lesão no maior eixo $(P=0,19)$, invasão venosa $(P=0,13)$ e grau de diferenciação celular $(P=0,19)$ não mostraram diferenças significantes em relação ao padrão de distribuição tecidual apical ou citoplasmático do CEA. Dos 47 doentes operados, 33 (70,2\%) sobreviveram mais de 5 anos e a sobrevivência média foi de 31,1 $\pm 5,6$ meses. A sobrevivência dos doentes com distribuição tecidual de CEA apical e citoplasmática não mostrou diferença significante $(P=0,38)$. Conclusões - Embora o padrão de distribuição apical do CEA tenha sido significantemente mais freqüente nos estádios menos avançados da classificação de Dukes, a distribuição tissular do CEA não apresentou relação com seus níveis plasmáticos, aspectos morfológicos da neoplasia e com a sobrevivência dos doentes com carcinoma colorretal operado com intenção curativa.

DESCRITORES - Neoplasias colorretais. Carcinoma. Antígeno carcinoembrionário. Imunoistoquímica.

\section{REFERENCES}

1. Ahnen DJ, Kinoshita K, Nakane PK, Brown WR. Differential expression carcinoembryonic antigen and secretory component during colonic epithelial cell differentiation and in colonic carcinomas. Gastroenterology. 1987;93:1330-8.

2. Bendardaf R, Lamlum H, Pyrhönen S. Prognostic and predictive molecular markers in colorectal carcinoma. Anticancer Res. 2004;24:2519-30.

3 Chiquillo Barber MT, Bort Martí J, Navarro Fos S. Pérez Bacete M, Esclápez Valero J, Gomez-Ferrer Bayo F. A correlation between serum levels of preoperative CEA and CEA immunohistochemical staining in colorectal carcinoma. Rev Esp Enferm Dig. 1993;83:249-54.

4. Chiquillo Barber MT, Navarro Fos S, Perez Bacete M, Esclapez Valero JP, Gomes-Ferrer Bayo F, Bort Marti J. The determination of tissue CEA in colorectal adenocarcinoma: an immunohistochemical study. Rev Esp Enferm Dig.1993;83:241-7.

5. Cosimelli M, De Peppo F, Castelli M, Giannarelli D, Schinaia G, Castaldo P, Buttini GL, Sciarretta F, Bigotti, Di Fillipo F, Cavalieri F, Cavalieri R. Multivariate analysis of a tissue CEA, TPA, and CA 19.9 quantitative study in colorectal cancer patients. A preliminary finding. Dis Colon Rectum. 1989;32:389-97.

6. Duffy MJ, van Dalen A, Haglund C, Hansson L, Klapdor R, Lamerz R, Nilsson O, Sturgeon C, Topolcan O. Clinical utility of biochemical markers in colorectal cancer: European Group on Tumour Markers (EGTM) guidelines. Eur J Cancer. 2003;39:718-27.

7. Forones NM, Tanaka M, Machado D, Falcão JB, Giovanoni M. Carcinoembryonic antigen in diagnosis and monotoring of colorectal cancer. Arq Gastroenterol. 1997;34:3-6.

8. Forones NM, Tanaka M, Machado D. Elevated carcinoembryonic antigen and absence of recurrence in monitoring colorectal cancer. Arq Gastroenterol. 1998;35:100-3.
9. Gebauer G, Muller-Ruchholtz W. Tumor marker concentrations in normal and malignant tissues of colorectal cancer patients and their prognostic relevance. Anticancer Res. 1997; 17:2939-42

10. Gold P, Freedman SO. Demonstration of tumor-specific antigens in human carcinoma by immunological tolerance and absorption techniques. J Exp Med. 1965;121:439-42.

11. Hamada Y, Yamamura M, Hioto K, Yamamoto M, Nagura H, Watanabe K. Immunohistochemical study of carcinoembryonic antigen in patients with colorectal cancer. Correlation with plasma carcinoembryonic antigen levels. Cancer. 1985;55:136-41.

12. Hammarstrom $S$. The carcinoembryonic antigen (CEA) family: structure, suggested functions and expression in normal and malignant tissue. Sem Cancer Biol. 1999;9:67-81.

13. Ilantzis C, DeMarte L, Screaton RA, Stanners CP. Deregulated expression of the human tumor marker CEA and CEA family member CEACAM6 disrupts tissue architecture and blocks colonocyte differentiation. Neoplasia. 2002;4:151-63.

14. Jantscheff P, Terracciano L, Lowy A, Glatz-Krieger K, Grunert F, Micheel B, Brümmer J, Laffer U, Metzger U, Herrmann R, Rochlitz C. Expression of CEACAM6 in resectable colorectal cancer: a factor of independent prognostic significance. J Clin Oncol. 2003;21:3638-46.

15. Lorenzi M, Vindigni C, Minacci C, Tripodi SA, Iroatulam A, Petrioli R, Francini G. Histopathological and prognostic evaluation of immunohistochemical findings in colorectal cancer. Int J Biol Markers. 1997;12:68-72.

16. Martinez CAR, Priolli DG, Cardinalli IA, Waisberg J, Margarido NF. Correlation between the standard of tissular expression and the serum values of the carcinoembryonic antigen in patients with colorectal cancer. Rev Bras Coloproctol. $2006 ; 26: 41-53$. 
17. Matos LL, Stabenow E, Tavares MR, Ferraz AR, Capelozzi VL, Pinhal MA Immunohistochemistry quantification by a digital computer-assisted method compared to semiquantitative analysis. Clinics. 2006;61:417-24.

18. Moreno Carretero G, Cerdan MFJ, Maestro CML, Martinez CS, Ortega MD, Pardo MM, Balibrea Cantero JL. Serum and tissue CEA in colorectal cancer: clinical relevance. Rev Esp Enferm Dig. 1998;90:391-401

19. Moura RM, Matos D, Galvão Filho MM, D'Ippólito G, Sjzenfeld J, Giuliano LM. Value of CEA level determination in gallbladder bile in the diagnosis of liver metastases secondary to colorectal adenocarcinoma. São Paulo Med J. 2001;119:110-3.

20. Nakagoe T, Sawai T, Ayabe H, Nakazaki T, Ishikaw H, Hatano K, Kajiwara K, Miyashita K, Matsuo T, Nogawa T, Arisawa K. Prognostic value of carcinoembryonic antigen (CEA) in tumor tissue of patients with colorectal cancer. Anticancer Res. 2001;21:3031-6.

21. Nakamura T, Tabuchi Y, Nakae S, Ohno M, Saitoh Y. Serum carcinoembryonic antigen levels and proliferating cell nuclear antigen labeling index for patients with colorectal carcinoma. Correlation with tumor progression and survival. Cancer. 1996;77:1741-6.

22. Ng IOL, Ho J, Pritchett CJ, Chan EY, Ho FCS. CEA tissue staining in colorectal cancer patients - correlation with plasma CEA, histology and staging. Pathology. 1993;25:219-22.

23. Sanders DS, Kerr MA. Lewis blood group and CEA related antigens; coexpressed cell-cell adhesion molecules with roles in the biological progression and dissemination of tumors. Mol Pathol. 1999;52:174-8.

24 Sharkey RM, Cardillo TM, Rossi EA, Chang CH, Karacay H, McBride WJ, Hansen HJ, Horak ID, Goldenberg DM. Signal amplification in molecular imaging by pretargeting a multivalent, bispecific antibody. Nat Med. 2005;11:1250-5.

25. Sutnar A, Pesta M, Liska V, Treska V, Skalicky T, Kormunda S, Topolcan O, Cerny R, Holubec L. Clinical relevance of the expression of mRNA of MMP-7, MMP-9, TIMP-1, TIMP-2 and CEA tissue samples from colorectal liver metastases. Tumour Biol. 2007;28:247-52

26. Tokunaga N, Kijima N, Noto T, Osamura Y, Sadahiro S, Tajima T, Mitomi T, Immunohistochemical localization of carcinoembryonic antigen as a predictor of lymph node status in submucosa-invasive colorectal carcinoma. Dis Colon Rectum. 1995;38:842-7.

27. Waisberg J, Landman G, Cha ASH, Henriques AC, Gaspar HA, Speranzini MB Standard of the tissular distribution of the CEA in the colorectal carcinoma: relation with the serical level of the CEA and Dukes' classification. Rev Bras Coloproctol. 2002;22:20-6.

28. Waisberg J, Palma RT, Neto LC, Martins LC, Oliveira MS, Nagashima CA, Godoy AC, Goffi FS. Biliary carcinoembryonic antigen levels in diagnosis of occult hepatic metastases from colorectal carcinoma. World J Gastroenterol. 2003;9:1589-93.

29. Waisberg J, Contim-Neto L, Oliveira MS, Matheus CO, Nagashima CA, Goffi FS. Determination of carcinoembryonic antigen levels in peripheral and draining venous blood in patients with colorectal carcinoma. Arq Gastroenterol. 2004;41:88-92.

30. Zeng Z, Cohen AM, Urmacher C. Usefulness of carcinoembryonic antigen monitoring despite normal preoperative values in node-positive colon cancer patients. Dis Colon Rectum. 1993;36:1063-8.

Recebido em 24/2/2008. Aprovado em 2/6/2008 